help reduce this loss of work she recommended the development in factories of Workers' Health Committees, as sub-committees of workers' committees or joint production committees. These new committees should act as workers' health and safety inspectors, should collaborate with medical men to conduct health education in factories, investigate the usefulness to workers of mental stimuli such as music and film shows, suggest arrangements for special cases such as antenatal examinations for pregnant workers, and co-operate with other health-promoting bodies in the district. She further suggested that the powers of local authorities under Section 8 of the Factory Act should be extended to cover cleanliness, ventilation, lighting, temperature and overcrowding; and that a State industrial medical service responsible to the Ministry of Health should be introduced, sharing and applying the results of research.

Dr. Mark Daniels, reviewing the state of the health services in the London boroughs, considered that many of the difficulties in health matters are due to inadequate use of the existing facilities. On the credit side, there had been no major epidemics, no fall in the level of nutrition of school children (except, significantly, in those entering school at age five), while communal feeding has been extended, and preferential treatment has been given by the Ministry of Food to heavy manual workers, expectant mothers and young children. On the debit side, there is the increase in tuberculosis, infantile mortality and deaths in childbirth, and a definite increase in diphtheria and venereal disease. Though the Ministries have made numbers of excellent recommendations, it is none too easy to get them carried out; the available arrangements are often not used to the full, owing to the inadequate education of the public in medical matters. He instanced the failure to make full use of facilities for immunization against diphtheria, for the treatment of venereal disease, and for the provision of cod liver oil and orange juice to expectant mothers. In his opinion, trade unions should lose no opportunity of raising health questions--should even devote whole conferences to health matters. To these conferences medical men should be invited so that they can get to know what the problems at hand really are. Trade unions could also assist in establishing the necessity for the provision of communal feeding centres, for shopping and transport facilities for workers, and for social and recreative facilities, especially for young persons. They could also help in petitioning for war-time nurseries and school canteens.

Sister Mary Morse contended that shortage of domestic staff aggravates the shortage of nurses, who are compelled to do non-nursing work. Nurses are overworked, and she said there is little doubt that the impossibility of giving proper attention to their patients, combined with delay in admitting sick persons to hospitals, greatly lengthens the period of illness. The shortage of nurses is due to the conditions under which nurses work in hospitals; she suggested that there is not much likelihood of improvement until nurses are organized, and the Essential Works Order and trade union machinery applied in hospitals. Though the Rushcliffe Report was a step in the right direction, the remuneration proposed for the very responsible ward sister is still inadequate, and domestic staff are not considered at all. 'The problem is urgent, as a 'second front' in Europe would make enormous demands on nurses.
Moreover, she considered it scandalous that while there is so great a shortage of medical men the majority of the teaching hospitals in London still refuse women students.

An immediate step towards the solution of the nursing problem would be the formation of a joint consultative committee of nurses and other hospital staff, which would determine the best way in which the limited resources of the hospitals could combine for the improvement of hospital services.

Resolutions embodying the main suggestions of the two openers were passed unanimously by the Conference.

\section{MEASUREMENT OF SHORT ELECTRIC WAVE-LENGTHS}

A $\mathrm{N}$ article with a mathematical basis entitled "Wavelength Measurements of Decimetric, Centimetric and Millimetric Waves" by A. G. Clavier (Elect. Comm., 20, No. 4 ; 1942) considers the measurement of waves shorter than one metre, and describes apparatus specially adapted to this purpose. The measurement of these wave-lengths presents peculiar difficulties and necessitates the construction of specialized apparatus.

In the region of decimetric waves, it is still possible to construct an oscillating circuit of lumped electrical constants. The selectivity of such a circuit can easily be estimated by means of its magnification factor, derivable from low-frequency technique.

Certain considerations presented in the paper and the necessity of finding an easy method of calibration in terms of wave-length have led to the use of eircuits with distributed constants and, in particular, transmission lines. In the first instance, transmission lines made up of two parallel Lecher wires were considered in which the separation between the wires is small compared with the wave-length; radiation can be ignored as a first approximation and Kirchhoff's laws applied by assigning line constants $R, L, C$ to the line. For very high frequencies, leakance between wires may also be ignored.

Transmission lines with parallel wires are especially suitable for decimetric wave-lengths; the resonance positions are repeated periodically along the line and their separation gives the wave-length to be measured. Such lines, with variations, have been used by numerous experimenters.

Lecher-wire wave-meters are in current use for the measurement of decimetric waves, but they have the following disadvantages. Line radiation increases with the frequency; it is difficult to localize the excitation at one point of the line; it is not easy to eliminate effects due to surrounding objects and movements of the operator. It is consequently preferable to use coaxial lines, and a wave-meter of this type was designed in 1931 .

Coaxial-line wave-meters may be used for the measurement of wave-length up to the centimetre wave-band. For wave-lengths of a few centimetres, however, the influence of the transverse dimensions of the coaxial line causes trouble, and coupling problems arise making dielectric guides necessary. The simplest of these consist merely of a metallic pipe without an inside conductor, and electromagnetic waves may be propagated through them provided the wave-length in air is below a certain 
limit which is of the order of the diameter of the guide.

To measure wave-lengths with dielectric guides, it is necessary to transform the wave-lengths measured along the guide into the wave-length in air. In the present state of the art and with transmitted frequency stability available, it is possible to rely on the theoretical relationships established between these wave-lengths. It is advisable to work fairly closely to the cut-off wave-length, since in this region a relatively small variation in the frequency causes a considerable variation in the wave-length along the axis of the guide.

Measurements of wave-lengths of less than one centimetre have been made with equipment illustrated in the paper. The wave-length of a magnetron especially constructed for wave-lengths of this order required determination. The magnetron sent an $H_{1}$ wave into a guide of $0.5 \mathrm{~cm}$. radius. A crystal detector was coupled to the guide and connected to a milliammeter. At the end of the guide a movable piston, which had very good high-frequency contacts with the wall of the guide, was displaced by a micrometer lead. Accuracy was increased by taking measurements at a certain number of half wave-lengths.

Other methods of measurement have been utilized. In particular, the quasioptical properties of these oscillations suggest the adaptation of interferometers and gratings. Thus, as might be expected, there is a tendency towards the technique of measurement used at the long end of the infra-red spectrum.

\section{FORTHCOMING EVENTS}

\section{(Meetings marked with an asterisk are open to the public)}

Saturday, March 13

TOWN AND COUNTRY PLANNING Assoctation (in the Council Chamber, Moreton-in-Marsh, Glos.), at 2 p.m.-Conference on "Reconstruction and Country Life" (Principal Speaker: Dr. C. S. Orwin)**

Monday, March 15 ASSOCIATION OF AUSTRIAN ENGINEERS, CHEMISTS $\triangle$ AND SCIENTIYTO
WORKRRS IN GREAT BRITAIN (at the Institution of Structural EnWORKRRS IN GREAT BRITAIN (at the Institution of Structural En-
gineers, 11 Upper Belgrave Street, London, $S$.W.1), at 7.30 p.m.-
Dr. K. Mendelssohn : "Low Temperature Research"."

Tuesday, March 16

RoYal SOCTETY OF ARTS (Dominions AND Colonims SEotion) (at John Adam Street, Adelphi, London, W.C.2), at 1.45 p.m.- - Sir Harry John Adam Street, Adelphi, London, W.C.2), at 1.45 p.m.- Sir Ha "H.

ROXAL INSTITUTION (at 21 Albemarle Street, Piccadilly, London, W.1), at 3 p.m.-Sir Henry Dale, G.B.E., P.R.S.: "Chemistry in Modern Medicinal Treatment", (i) "Pre-scientifle Discoveries"."

MANCHESTER LITERARY AND PHILOSOPHICAI SOCIETY (in Room “o. 7, The University, Manchester), at 5 p.m. Mr. A. L. Armstrong: covery of a Figurine of the Mother Goddess, associated with evidence of Ritual Worship".

Wednesday, March 17

ROYAI SOCIETY of ARTS (at John Adam Street, Adelphi, London, W.C.2), at 1.45 p.m.-Mr. W. P. Hildred: "The F'uture of Air Transport".

INSTTTUTE OF PHYSICS (JOINT MEETING WITH THB LONDON AND SOUTH-EASTERN COUNTIES' SECTION OF THE INSTITUTE OF CHFMTSTRY) (at the Royal Institution, 21 Albemarle Street, Piccadilly, London, GEOLOGIOAL Societry of LONDON (at Burlington House, Piccadilly, London, W.1), at 3 p.m.-Annual General Meeting.

ROYaL METEorologidal Society (at 49 Cromwell Road, South Kensington, London, S.W.7), at 4.30 p.m.-Prof. Herbert Dingle : "Atoms, Molecules and Radiation" (G. J. Symons Memorial Lecture).

Thursday, March 18

London Mathematical Societr (at the Royal Astronomical Society, Burlington House, Piceadilly, London, W.1), at 3 p.m.Prof. H. Simpson: "Some Problems in Statistical Theory".

ASSOCIATION OF SCIENTIFTC WORKERS (IN CO-OPERATION WITH THE WOOLWICH AMENITIES CoMMiTTEe) (in the Council Chamber, Town Hall, Woolwich, London, S.E.18), at 7.15 p.m.-Sir Robert WatsonWatt, F.R.S.: "The Scientific and Technical Worker in the Public Service".
Friday, March 19

ROYAI INSTITUTION (at 21 Albemarle Street, Piccadilly, London W.1), at, 5 p.m.- Sir Alfred Egerton, F.R.S.: "Warmth and Comfort

\section{Saturday, March 20-Sunday, March 21}

BRITISH Assoctation (DIvision FOR THE SOCIAL AND INTERNATIONAL RELATIONS OF SOIENCE) (at the Royal Institution, 21 Albemarle Street, Piccadilly, London, W.1). Conference on "Science and the Citizen, the Public Understanding of Science".*

Saturday, March 20

10 a.m.- "The Exposition of Science"

(Chairman : Sir Henry Dale, G.B.E., P.R.S.).

2.15 p.m. "Radio and the Cinema".

(Chairman : Sir Allan Powell).

Sunday, March 21

10 a.m.- "Science as a Humanity". (Chairman : Prof. J. L. Myres).

2.15 p.m.- "Science and the Press".

(Chairman : Sir Richard Gregory, Bart., F.R.S.).

\section{APPOINTMENTS VACANT}

Appicications a de invited for the following appointments on or before the dates mentioned:

ASSISTANT MASTER TO TEAOH PRINCIPALLY ENGINEERING WORKSHOP PRACTTCE AND DRAWING, in the Junior Technical School of Whitwood Technical College-Mr. M. G. Swaine, 97 Smawthorne Lane, Castleford, Yorks. (March 20).

Teacher of Mathematics, Techicical Drawing, and ONE WorkSHOP SUBJECT, PREFRRABLY WOODWORK OR JOINERY AND CARPENTRY, in the Dinnington-Chelmsford Junior Technical School-Mr. G. E.

TEACHERS FOR $(a)$ MEChaNTCAL ENGINEERTNG SUBJEOTS, $(b)$ MATHEMATICS AND PHYSICS, in the Smethwick Municipal College-The Chief Education Officer, Education Offices, 215 High Street, Smethwick 41 (March 22).

LeCturers in (a) Mechanical Engineerivg, (b) Electrioal ENGINEARING- The Registrar, Loughborough College, Loughborough, Leics. (March 22)

DEPUTY ChIEF ENGINeER aND MaNager of THF Birmingham 14 Dale End, Birmingham (endorsed 'Deputy Chief Engineer and Manager') (March 30).

ChAIR OF CHEMISTRY in the University College of North WalesThe Bursar and Acting Registrar, University College of North Wales, Bangor (April 3)

SPEECH THERAPIST-The Education Offlcer, County Hall, Wakefleld. LECTURER IN ENGuISH for British Institute, Leopoldville, Belgian Congo to teach English to European adults and assist in Cultura Activities-The British Council, 3 Hanover Street, London, W.1 (endorsed 'Leopoldville').

ASSISTANT WORKS MANAGER (OPTICAL) for new instrument factory, Indian Ordnance Services-The Ministry of Labour and National Service, Central (Technical and Scientific) Register, Ref. C.1500, Alexandra House, Kingsway, London, W.C.2

LECTURERS (FULJ-TIME OR PART-TIME) IN MFOHANIOAL AND ELEOTRICAI, ENGINEERING SUBJECTS - The Ministry of Labour and National Service, Central (Technical and Scientiffc) Register, Section D.565, Alexandra House, Kingsway, Xondon, W.C.2.

\section{REPORTS and other PUBLICATIONS}

(not included in the monthly Books Supplement)

\section{Great Britain and Ireland}

University of Birmingham. Report of the Vice-Chancellor and Principal to the Council for the Forty-second Session 1941-1942. Pp. 20. (Birmingham: The University.)

\section{Other Countries}

New Zealand. Sixteenth Annual Report of the Department of Scientific and Industrial Research. Pp. 34. (Wellington: Govern-
ment Printer.) 18.
[291] [291
Smithsonian Institution. War Background Studies, No. 4 : Peoples of the Philippines. By Herbert W. Krieger. (Publication 3694.) Pp. iv $+86+24$ plates. (Washington, D.C.: Smithsonian Institu-
tion.)

University of Florida Publication. Biological Science Series, Vol. 3, No. 2: The Crayfishes of Florida. By Horton H. Hobbs, Jr. Pp. $\nabla+179+24$.plates. 2.25 dollars. Biological Science Series, Vol. 4 , No. 1: The Plant Communities of the Welaka Area, with Special Reference to Correlations between Soils and Vegetational Succession. By Albert Middleton Laessle. Pp. 143 (14 plates). 1.50 dollars.
[Gainesville, Fla.: Univergity of Florida.)

Smithsonian Miscellaneous Collections. Vol. 103, No. 6: On the Preparation and Preservation of Insects, with particular reference to Coleoptera. By J. Manson Valentine. (Publication 3696.) Pp. ii +16. (Washington, D.C.: : Smithsonian Institution.) 